\title{
Physiological Characterisation of Alternaria brassicicola causing Alternaria Leaf Spot in Cabbage
}

\author{
Gunda V.N.S. Madhu Kiran*, S.S. Thara and Sree Pavan \\ Department of Plant Pathology, College of Agriculture, Vellayani, Kerala Agricultural \\ University, India \\ *Corresponding author
}

Ke y w o r d s
$\begin{aligned} & \text { A.brassicicola, } \\ & \text { Cabbage, In vitro, } \\ & \text { Physiological studies }\end{aligned}$
Article Info
Accepted:
20 September 2018
Available Online:
10 October 2018

Cabbage is a cool season crop grown in temperate regions and belongs to family Brassicaceae. In Kerala, cabbage is grown in an area of 197 ha and major cultivated regions were Idukki and Wayanad districts. The leaf spot of cabbage is caused by Alternaria brassicicola is a widespread disease affecting the yield of cabbage. This disease can be managed by using fungicides or bioagents but the efficacy of these measures depend on host pathogen interaction, which is influenced by environmental factors. The present study was undertaken to study the effect of Temperature, $\mathrm{pH}$ levels and Light intensity on the growth of $A$. brassicicola as the growth and development of pathogen was influenced by the environmental factors. Studies on physiological characters revealed that optimum temperature for the growth of $A$. brassicicola was $25^{\circ} \mathrm{C}$. The pathogen was completely inhibited at $35^{\circ} \mathrm{C}$ and moderate growth was recorded at $20^{\circ} \mathrm{C}$ and $30^{\circ} \mathrm{C}$. The ideal $\mathrm{pH}$ for the growth of pathogen was 5.5 and 6 . The optimum light intensity favoured the growth of pathogen was normal day and night condition (20 lux) followed by dark. The growth and sporulation was affected at higher light intensities.

\section{Introduction}

Cabbage (Brassica oleracea var. capitata) is an economically important vegetable crop which forms a compact head with leaves and grown as biennial for the production of seeds. It is a cool season crop grown in temperate regions and belongs to family Brassicaceae. Cabbage has its centre of origin in Mediterranean regions and now its cultivation is seen all over the world due to its nutritional benefits. It is mostly cultivated under temperate conditions as a rabi season crop and as cool season crop in the tropics.
Cabbage production is affected by many fungal, bacterial and viral diseases at different stages of growth and development. Among fungal diseases, clubroot, Alternaria leaf spot and damping off are the most prominent and destructive ones affecting the yield of cabbage. Alternaria leaf spot of cabbage caused by $A$. brassicicola is a widespread disease affecting the yield of cabbage worldwide.

Ansari (1988) stated that initial symptoms of A. brassicicola were dark spots on the lower leaves of cabbage and caused damping off 
during seedling stage. These dark spots on leaves ranged in size from one to four $\mathrm{cm}$ in diameter and developed concentric rings within the spots (Dillard et al., 1997). As the disease progressed these spots merged together on leaf and reduced the photosynthetic ability of plant (Kucharek, 2000). Later the infection appeared on the reproductive parts of the plant and caused significant yield losses in cabbage (Doullah et al., 2006).

Dillard et al., (1997) stated that most favourable temperature for growth and sporulation of A.brassicicola was $20-30^{\circ} \mathrm{C}$ in cabbage but optimum temperature for infection and conidial germination in cabbage was $25^{\circ} \mathrm{C}$ and $28-31^{\circ} \mathrm{C}$ respectively. Mehta (2014) stated that the congenial temperature for the growth and sporulation of A.brassicicola was $25^{\circ} \mathrm{C}$ and also reported that optimum temperature required for the development of disease was $12-25^{\circ} \mathrm{C}$ and relative humidity should be more than $70 \%$ in rapeseed-mustard. Singh (1980) reported that for mean mycelial growth and conidial development of A.brassicicola, the ideal was at pH 5.5. Hubbali et al., (2010) reported that average growth of mycelium was highest at pH 6-6.5 for A. alternata. Alhussaen (2012) and Chohan et al., (2015) stated that best hydrogen ion concentration for the growth of A.solani range from $\mathrm{pH} 6$ to 7 .

Hubballi et al., (2010) conducted a study and determined the effect of light on the growth of A. alternata and observed that the radial growth of the pathogen was highest $(8.7 \mathrm{~cm})$ at $12 \mathrm{~h}$ of alternate light and dark condition compared to continuous darkness and light intensity. Mehta (2014) studied the effect of light on the sporulation of $A$. brassicicola and reported that growth and sporulation was inhibited at higher light intensity (>1000 lux) and vice versa with darkness and less intensity of light.

\section{Materials and Methods}

\section{Isolation}

The cabbage leaves infected with Alternaria spp. were collected during the survey and isolation was done by cutting small pieces of diseased portion of leaf along with healthy portion and immersed in mercuric chloride solution $(0.1 \%)$ for 30 seconds.

Then these leaf bits were washed thrice in sterile water and placed aseptically on the sterile petriplate which was poured with the sterilized potato dextrose agar (PDA) medium (Rahimloo and Ghosta, 2015). These plates were incubated at room temperature $\left(27 \pm 4^{\circ} \mathrm{C}\right)$ for proper development of the pathogen. Pure culture of the fungus was obtained by hyphal tip isolation method.

\section{Physiological studies}

\section{Effect of temperature on growth of pathogen}

The growth of virulent pathogen was tested at five different temperatures viz., $15^{\circ} \mathrm{C}, 20^{\circ} \mathrm{C}$, $25^{\circ} \mathrm{C}, 30^{\circ} \mathrm{C}$ and $35^{\circ} \mathrm{C}$. For this, PDA medium was prepared and sterilized. Then melted and cooled PDA medium was poured in sterilized petriplates. Five mm fungal discs of pathogen were taken from seven days old culture and inoculated at the centre of the petriplate under aseptic conditions. Four replications were maintained for each treatment. Then these plates were incubated at different temperatures and observations on radial growth was recorded when pathogen attained full growth in the petriplate at any one treatment.

\section{Effect of pH on growth of pathogen}

In order to study the effect of $\mathrm{pH}$ on the growth of pathogen, PDA medium \pm were prepared having different $\mathrm{pH}$ range 4.0, 4.5, 
5.0, 5.5 and 6.0. The $\mathrm{pH}$ levels of this PDA media were adjusted by adding acid $(\mathrm{HCl})$ or alkali $(\mathrm{NaOH})$ to get the desired $\mathrm{pH}$. PDA medium of respective $\mathrm{pH}$ were poured into the sterilized petriplates separately and four replications were maintained for each $\mathrm{pH}$. Then five mm disc of fungus were taken from seven days old culture pathogen using sterile cork borer and inoculated at the centre of petriplate.

These plates were incubated at room temperature $\left(27 \pm 4^{0} \mathrm{C}\right)$. Observation were taken on the radial growth of the pathogen $(\mathrm{cm})$ when the fungi attained full growth at any one of $\mathrm{pH}$ levels tested.

\section{Effect of light on growth of pathogen}

The virulent pathogen were grown at different light intensities 1000 lux, 2000 lux, 3000 lux, dark condition and normal day and night condition to determine the influence of light on the growth of pathogen. For this, sterilized PDA medium was prepared and poured into sterilized petriplates in laminar airflow chamber. Then five mm mycelial bits of the pathogen were taken from the 7 day old culture and inoculated at the centre of petriplate and they were incubated at respective light intensities. Four replications were maintained for each treatment and observations were noted when the fungus attained full growth in the petriplate at any one of the light intensities. Light intensities were measured by using the lux meter. By using the lux meter the distance from the light source has been determined at which the required light intensity is attained.

\section{Results and Discussion}

\section{Isolation}

Pure culture of the pathogen obtained from the cabbage leaves exhibiting typical blight symptoms were identified as A.brassicicola based on the morphological characteristics according to Alternaria identification manual (Simmons, 2007).

\section{Physiological studies}

\section{Effect of temperature on growth of pathogen}

The pathogen was grown at different temperatures i.e., $15,20,25,30$ and $35^{\circ} \mathrm{C}$ on the PDA medium to determine the optimum temperature for the growth of pathogen. The results showed that the treatments differ significantly.

The growth of the pathogen was maximum at $25^{\circ} \mathrm{C}(9 \mathrm{~cm})$ followed by $20^{\circ} \mathrm{C}(6.3 \mathrm{~cm})$. The growth was completely inhibited at $35^{\circ} \mathrm{C}$. Optimum temperature for the growth of pathogen was observed as $25^{\circ} \mathrm{C}$ and growth was inhibited with further increase or decrease in temperature (Table 1, Plate 1).

Humpherson-jones and Phelps, (1989) and Dillard et al., (1997) reported that the growth of the pathogen was maximum at temperature $25-30^{\circ} \mathrm{C}$. In the present study, the growth of $A$. brassicicola was moderate at temperature $20^{\circ} \mathrm{C}$ and $30^{\circ} \mathrm{C}$ (Fig. 1) consistent with results of Alhussaen (2012) and Mehta (2014).

\section{Effect of pH on growth of pathogen}

The growth of the pathogen was tested under in vitro condition at six acidic $(4,4.5,5,5.5,6$ and 6.5) and one neutral (7) $\mathrm{pH}$ conditions. The results from in vitro evaluation showed that the radial growth of the pathogen was maximum at $\mathrm{pH}-5.5(9 \mathrm{~cm})$ and $6(9 \mathrm{~cm})$. This was followed by $\mathrm{pH} 6.5(8.6 \mathrm{~cm}), \mathrm{pH} 5$ (8.4) and $\mathrm{pH}$ (4.5) which was on par with each other. The least growth of the pathogen recorded was $7.6 \mathrm{~cm}$ at $\mathrm{pH} 7$ (Table 2, Fig. 2, Plate 2). 
Table.1 Effect of temperature on the growth of A. brassicicola

\begin{tabular}{|c|c|c|}
\hline SI. No. & Temperature $\left({ }^{\circ} \mathrm{C}\right)$ & Radial growth* $(\mathbf{c m})$ \\
\hline 1 & 15 & $2.9 \pm 0.3^{\mathrm{d}}$ \\
\hline $\mathbf{2}$ & 20 & $6.3 \pm 0.4^{\mathrm{b}}$ \\
\hline $\mathbf{3}$ & 25 & $9.0 \pm 0.0^{\mathrm{a}}$ \\
\hline $\mathbf{4}$ & 30 & $4.1 \pm 0.2^{\mathrm{b}}$ \\
\hline $\mathbf{5}$ & 35 & $\mathrm{Nil}$ \\
\hline & $\mathrm{CD}(0.05)$ & 0.29 \\
\hline & $\mathrm{SE}$ & 0.13 \\
\hline
\end{tabular}

*Mean of four replications

Table.2 Effect of $\mathrm{pH}$ on the growth of A. brassicicola

\begin{tabular}{|c|c|c|}
\hline Sl. No. & Ph & Radial growth $*(\mathrm{~cm})$ \\
\hline 1 & 4.0 & $7.6 \pm 0.3^{\mathrm{d}}$ \\
\hline 2 & 4.5 & $8.1 \pm 0.3^{\mathrm{c}}$ \\
\hline 3 & 5.0 & $8.4 \pm 0.1^{\mathrm{bc}}$ \\
\hline 4 & 5.5 & $9.0 \pm 0.0^{\mathrm{a}}$ \\
\hline 5 & 6.0 & $9.0 \pm 0.0^{\mathrm{a}}$ \\
\hline 6 & 6.5 & $8.6 \pm 0.1^{\mathrm{b}}$ \\
\hline 7 & 7 & $6.8 \pm 0.5^{\mathrm{e}}$ \\
\hline & $\mathrm{CD}(0.05)$ & 0.30 \\
\hline & $\mathrm{SE}$ & 0.154 \\
\hline
\end{tabular}

*Mean of four replications

Table.3 Effect of light on the growth of A. brassicicola

\begin{tabular}{|c|c|c|}
\hline SI. No. & Intensity of light & Radial growth* $(\mathbf{c m})$ \\
\hline $\mathbf{1}$ & Dark & $8.5 \pm 0.2^{\mathrm{b}}$ \\
\hline $\mathbf{2}$ & 1000 lux & $8.3 \pm 0.2^{\mathrm{c}}$ \\
\hline $\mathbf{3}$ & 2000 lux & $8.1 \pm 0.3^{\mathrm{d}}$ \\
\hline $\mathbf{4}$ & 3000 lux & $7.8 \pm 0.4^{\mathrm{e}}$ \\
\hline $\mathbf{5}$ & Normal day and night condition & $9.0 \pm 0.0^{\mathrm{a}}$ \\
\hline & CD $(0.05$ level $)$ & 0.4 \\
\hline & SE & 0.134 \\
\hline
\end{tabular}

*Mean of four replications 
Fig.1 Effect of temperature on growth of A. brassicicola

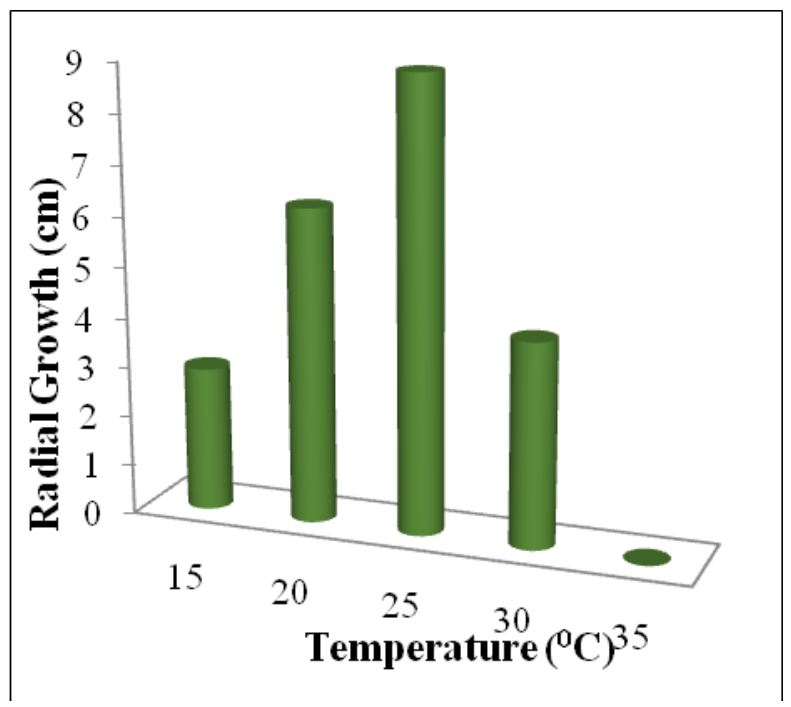

Fig.2 Effect of pH on growth of A. brassicicola

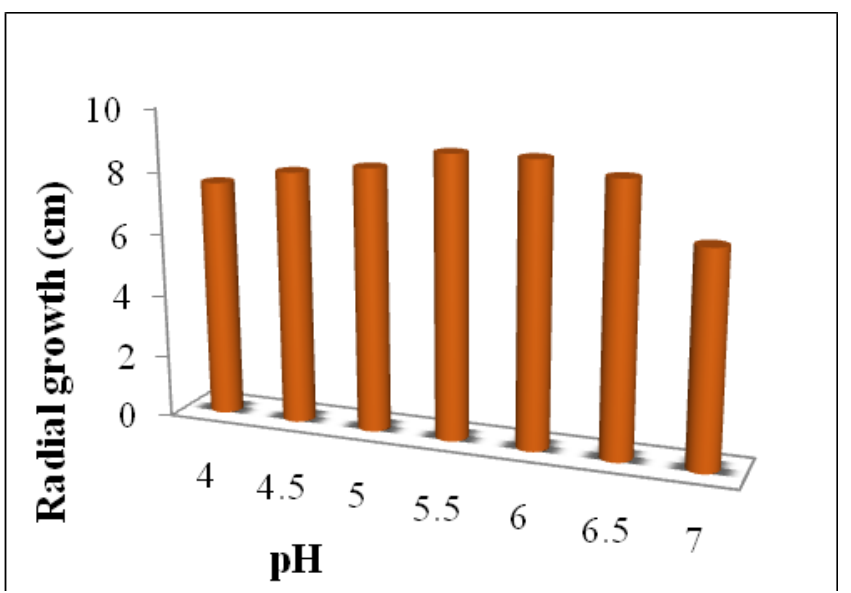

Fig.3 Effect of light intensity on growth of A. brassicicola

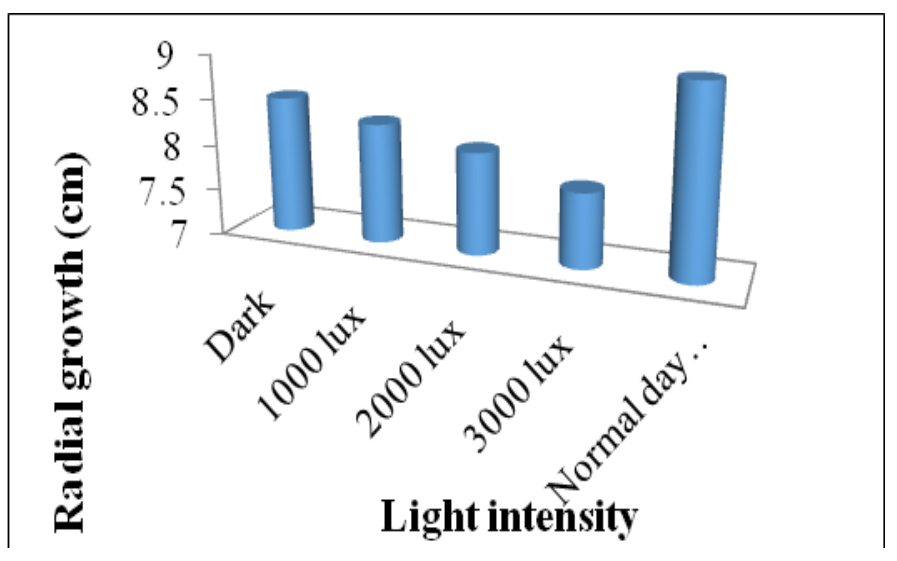


Int.J.Curr.Microbiol.App.Sci (2018) 7(10): 2727-2734

Plate.1 Radial growth of $A$. brassicicola at different temperature

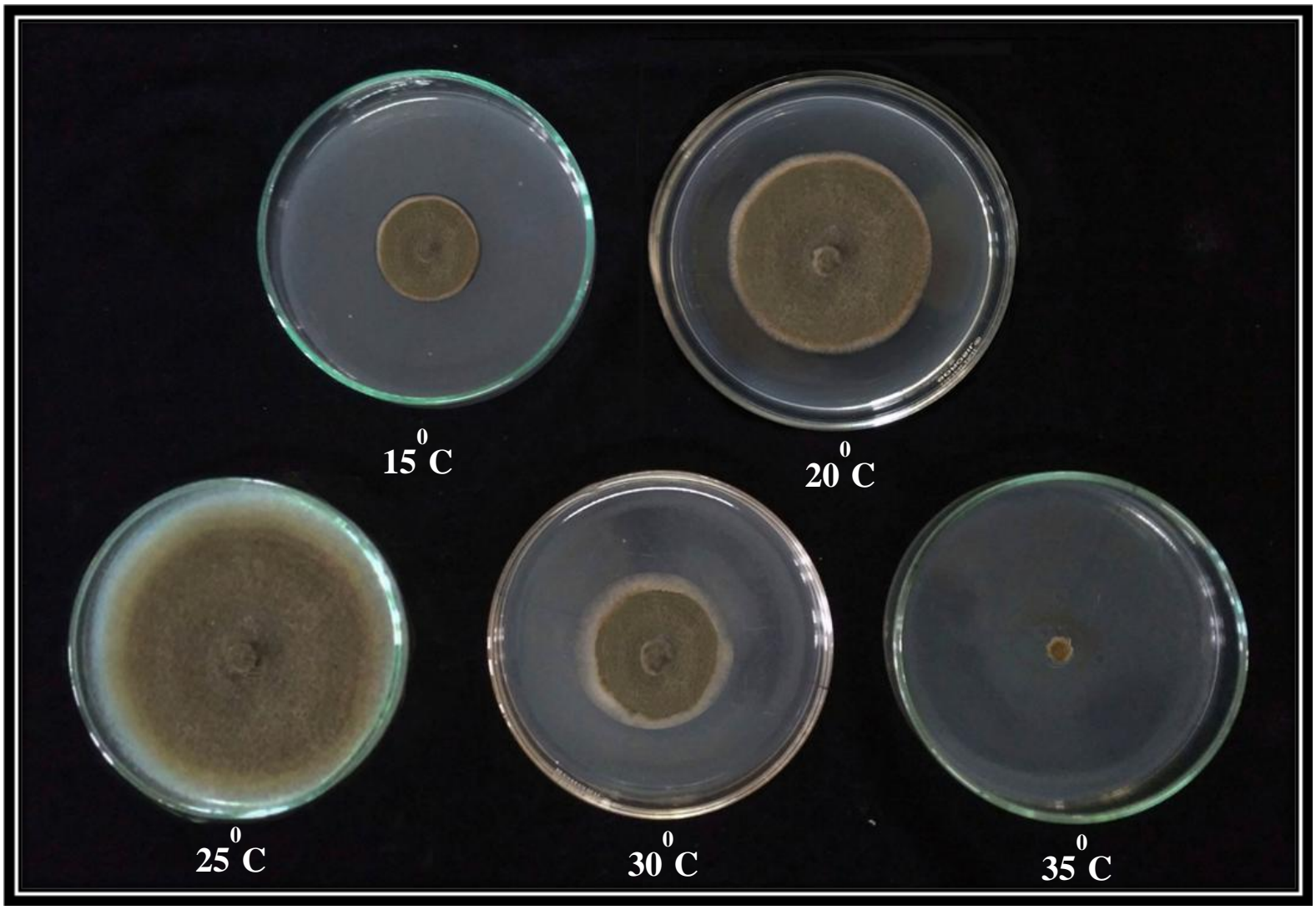

Plate.2 Radial growth of $A$. brassicicola at different $\mathrm{pH}$

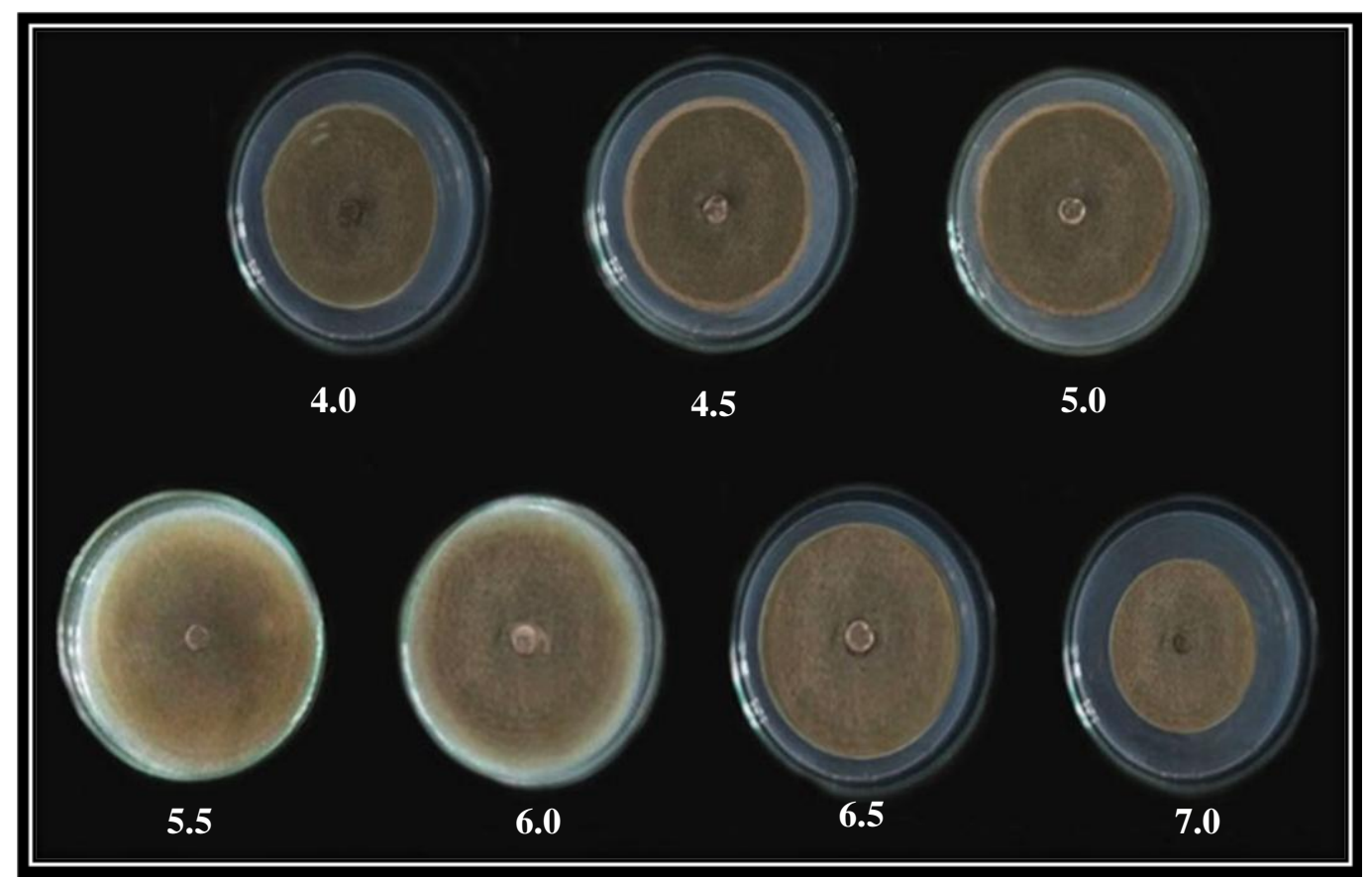


Plate.3 Radial growth of A. brassicicola at different light intensity

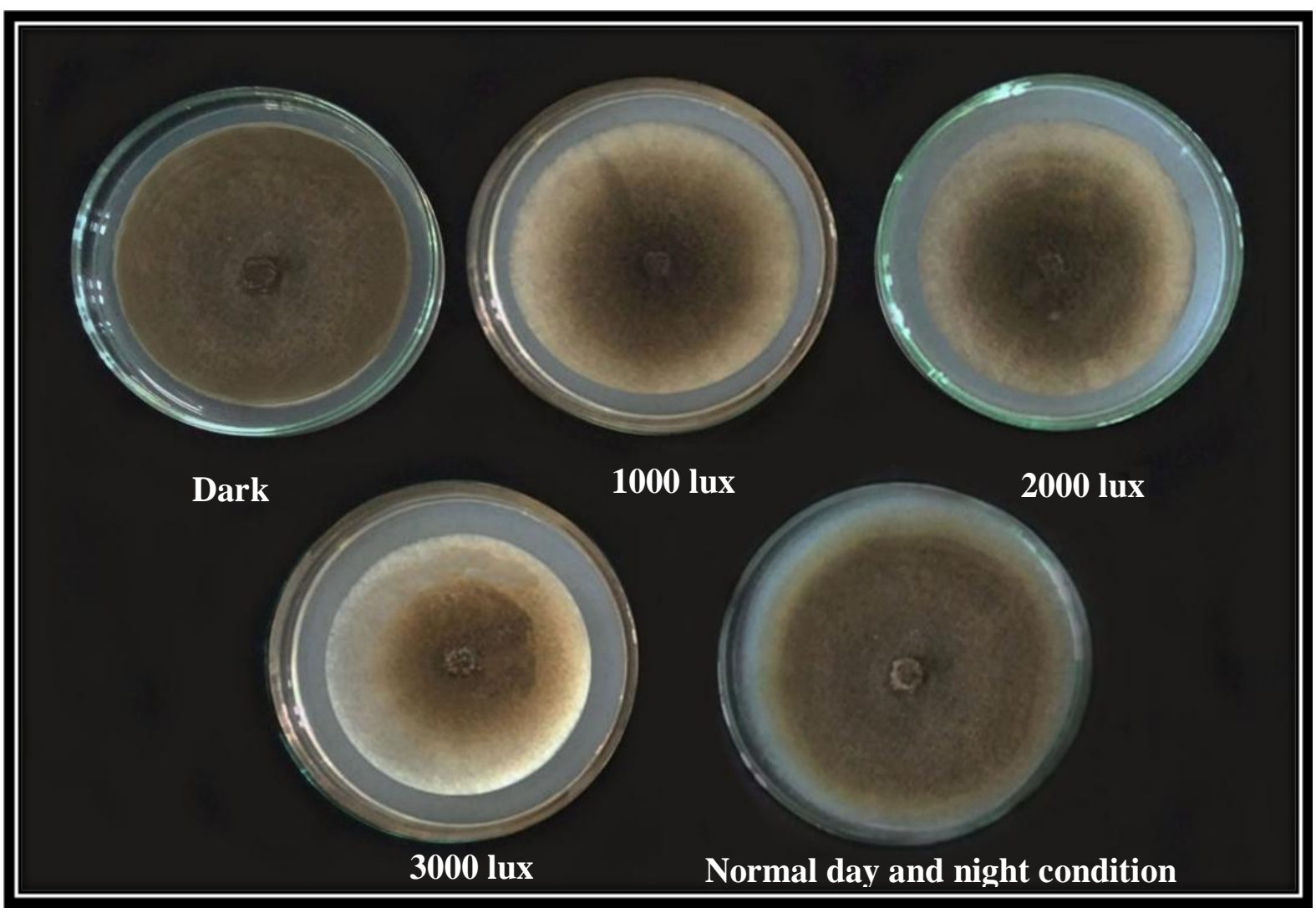

The results from this in vitro study were similar to the results of Kumar (1978), Singh (1980) and Pradnyarani and Kulkarni (2015) but differ with the results of Chohan et al., (2015), Gawai and Mangnalikar (2017) as the ideal hydrogen ion concentration for the growth of pathogen was observed at $\mathrm{pH} 6.5$.

\section{Effect of light on the growth of pathogen}

The pathogen was exposed to different light conditions i.e., dark, 1000 lux, 2000 lux, 3000 lux and normal day and night conditions (20 lux) to determine the optimum light intensity for the growth of the pathogen. The results revealed that the radial growth of the pathogen was highest at normal day and night condition $(9 \mathrm{~cm})$. This was followed by the dark $(8.5 \mathrm{~cm}), 1000$ lux $(8.3 \mathrm{~cm}), 2000$ lux $(8.1 \mathrm{~cm})$ and 3000 lux $(7.8 \mathrm{~cm})$ which were on par with each other (Table 3, Plate 3).
These results showed similarity with the results of Naik (2010) and Hubbali et al., (2010) (Fig. 3). The growth of the pathogen declined with increase in light intensity and these results were in agreement with Lukens (1963) and Humpherson-jones and Phelps (1989).

\section{References}

Alhussaen, K. M. 2012. Morphological and physiological characterization of Alternaria solani isolated from tomato in Jordan valley. Res. J. Biol. Sci. 7(8): 316-319.

Ansari, N. A. 1988. Identity and cultural characters of the pathogen causing Alternaria blight of rapeseed and mustard. J. Oilseeds Res. 5(2): 80-88.

Chohan, S., Perveen, R., Mehmood, M. A., Naz, S., and Akram, N. 2015. Morpho- 
physiological studies, management and screening of tomato germplasm against Alternaria solani, the causal agent of tomato early leaf blight. Int. J. Agric. Biol. 17: 111-118.

Dillard, H. R., Cobb, A. C., and Lamboy, J. S. 1997. Transmission of Alternaria brassicicola to cabbage by flea beetles (Phyllotreta cruciferae). Plant Dis. 82:153-157.

Doullah, M. A. U., Meah, M. B., and Okazaki, K. 2006. Development of an effective screening method for partial resistance to Alternaria brassicicola (dark leaf spot) in Brassica rapa. Eur. J. Plant Pathol. 116: 33-43.

Gawai, D. U. and Mangnalikar, S. S. 2017. Effect of temperature and $\mathrm{pH}$ on the growth of Alternaria alternata, leaf spot pathogen of soyabean. Biosci. Discov. 9(1): 162-165.

Hubbali, M., Nakkeeran, S., Raguchander, T., Anand, T., and Samiyappan, R. 2010. Effect of environmental conditions on the growth of Alternaria alternata causing leaf blight of noni. World $J$. Agric. Sci. 6(2): 171-177.

Humpherson-jones, F. M. and Phelps, K. 1989. Climatic factors influencing spore production in Alternaria brassicae and Alternaria brassicicola. Ann. Appl. Biol. 114(3): 449-458.

Kucharek, T. 2000. Alternaria diseases of crucifers. Plant Pathol. 7(3): 34-38
Kumar, V. R. 1978. Nutritional requirements of Alternaria triticina in wheat. Geobios. 5(1): 12-15.

Lukens, R. J. 1963. Photo inhibition of sporulation in Alternaria solani. Am. J. Bot. 50(7): 720-724.

Mehta, N. 2014. Epidemiology and forecasting for the management of Rapeseed-mustard diseases. J Mycol. Pl. Pathol. 44(2): 131-147.

Naik, M. K. 2010. Morphological, physiological, pathogenic and molecular variability among isolates of Alternaria solani from tomato. Indian Phytopath. 63(2): 168-173.

Pradnyarani, N. and Kulkarni, M. S. 2015. Effect of different $\mathrm{pH}$, temperature and solid media on growth of purple blotch of onion caused by Alternaria porri Ellis. Bioscan. 10(4): 1839-1843.

Rahimloo, T. and Ghosta, Y. 2015. The occurrence of Alternaria species on cabbage in iran. Zemdirbyste. Agric. 102(3): 343-350.

Simmons, E. 2007. Alternaria: An identification manual. CBS fungal biodiversity centre, Utrecht, Netherlands.

Singh, D. B. 1980. Effect of culture media, $\mathrm{pH}$, temperature on growth behaviour of Alternaria brassicae and Drechsler agraminae. Ann. Plant Prot. 46(3): 393396.

\section{How to cite this article:}

Gunda V.N.S. Madhu Kiran, S.S. Thara and Sree Pavan. 2018. Physiological Characterisation of Alternaria brassicicola causing Alternaria Leaf Spot in Cabbage. Int.J.Curr.Microbiol.App.Sci. 7(10): 2727-2734. doi: https://doi.org/10.20546/ijcmas.2018.710.317 